\title{
ANALISIS MADZHAB SYAFI'I TERHADAP FATWA MUI TENTANG AKAD QARDH
}

\author{
Abdul Kholiq Syafa'at ${ }^{1}$, M. Afnan Afandi ${ }^{2}$ \\ Universitas Islam Negeri Sunan Ampel Surabaya ${ }^{1}$ \\ Institut Agama Islam Darussalam Banyuwangi ${ }^{2}$ \\ Email: abdulkholiqsyafaat@gmail.com¹.mas.afnan01@gmail,com²
}

\begin{abstract}
The purpose of this research is to analyze the Syafi'i Madzhab against the MUI fatwa regarding the Qardh Akad. The type of research used is qualitative research and is descriptive analysis. The MUI fatwa which explains al-Qardh itself has been stated in the MUI DSN fatwa No. 19 / DSN-MUI / IV / 2001 on alQardh which includes; general provisions, sanctions, sources of funds, and other provisions. The research method is a qualitative method with a naturalistic type. The results of this study conclude that the DSN-MUI Fatwa regarding the Qardh contract is following the qardh concept established by the Syafi'i school, both in terms of law and its consequences, it's just that there are several points from the fatwa researchers have not been able to conclude through the mu'tabarah books of the Shafi'i school.
\end{abstract}

\section{Keywords: Madzhab Syafi'i, Akad Qardh}

\begin{abstract}
Abstrak
Tujuan dari penelitian ini adalah menganalisis Madzhab Syafi'i terhadap fatwa MUI tentang Akad Qardh. Jenis penelitian yang digunakan adalah penelitian kualitatif dan bersifat deskriptif analisis.Fatwa MUI yang menjelaskan tentang alQardh sendiri telah tertuang pada fatwa DSN MUI No. 19/DSN-MUI/IV/2001 tentang al-Qardh yang meliputi; ketentuan umum, sanksi, sumber dana, maupun ketentuan lainnya. Metode penelitian adalah metode kualitatif dengan jenis naturalistik Hasil penelitian ini menyimpulkan bahwa Fatwa DSN-MUI tentang akad Qardh telah sesuai dengan konsep qardh yang telah ditetapkan oleh madzhab Syafi'i, baik dalam ketentuan hukum maupun konsekuensinya, hanya saja ada beberapa poin dari fatwa tersebut yang belum dapat peneliti simpulkan melalui kitab-kitab mu'tabarah madzhab Syafi'i.
\end{abstract}

\section{Kata Kunci: Madzhab Syafi'i, Akad Qardh}

\section{A. Pendahuluan}

Pembahasan tentang ekonomi memang tidak akan pernah habis seiring berjalannya waktu. Karena ekonomi merupakan salah satu kebutuhan utama setiap 
orang dalam menjalankan tugasnya sebagai khalifah Allah dimuka bumi ini. Dalam perjalanannyapun kini muncul berbagai usaha bisnis dan lembaga yang membantu pemenuhan kebutuhan manusia yang dikenal dengan istilah lembaga keuangan.

Dewasa ini, rasanya telinga kita tidak lagi merasa asing ketika mendengar kata "Lembaga Keuangan Syariah". Pengembangan ekonomi di Indonesia telah diadopsi dalam kerangka besar ekonomi. Setidaknya, bank indonesia sebagai salah satu pilar penyangga dual-banking system dan mendorong pangsa pasar bank-bank syariah yang lebih luas sesuai cetak biru perbankan syariah (Bank Indonesia, 2002).

Begitu juga, Departemen Keuangan melalui melalui Badan Pengawas Pasar Modal dan Lembaga Keuangan (Bapepam LK) telah mengakui keberadaan lembaga keuangan Syariah nonbank seperti asuransi dan pasar modal syariah. Sementara itu, Departemen Agama telah mengeluarkan akreditasi bagi organisasiorganisasi pengelola zakat, baik ditingkat pusat maupu daerah (Mahmud dan Rukmana, 2010:3).

Lembaga Keuangan Syariah (LKS) merupakan lembaga keuangan yang mengeluarkan produk keuangan syariah dan mendapat izin operasional sebagai lembaga keuangan syariah. Agar lembaga keuangan syariah dapat berjalan sesuai dengan pengertian dan fungsinya, tentu perlu adanya suatu badan yang mengatur dan menetapkan prinsip-prinsip hukum Islam. Oleh karena itulah, pada tahun 1999, Majelis Ulama Indonesia (MUI) membentuk Dewan Syariah Nasional (DSN) sebagaimana dituturkan Badan Pelaksana Harian (BPH) Dewan Syariah Nasional MUI yang fungsi utamanya untuk menangani masalah-masalah yang berhubungan dengan aktivitas lembaga keuangan syariah (Dewan Syariah Nasional MUI 2014:4).

Berdasarkan pada SK Dewan Pimpinan MUI tentang Pembentukan Dewan Syariah Nasional (DSN) No. Kep-754/MUI/II/1999, yaitu bahwa salah satu yang menjadi tugas dan wewenang DSN ialah mengeluarkan fatwa (Dewan Syariah Nasional MUI 2014:7). Hal ini untuk menganalisis fatwa MUI, khususnya tentang akad Qardh.

Jurnal Darussalam; Jurnal Pendidikan, Komunikasi dan Pemikiran Hukum Islam Vol. XI, No 2:408-423. April 2020. ISSN: 1978-4767 (Cetak), ISSN: 2549-4171(Online) Terakreditasi Nasional. SK. No.36/E/KPT/2019 


\section{B. Landasan Teori}

\section{Definisi Akad Qardh menurut Fuqoha'}

Secara etimologi yang dikemukakan oleh Abu Abdul mu'thi Muhammad bin Umar bin Ali Nawawi (2003:240) bahwa Qardh berarti pinjaman utang (muqradh) atau memberikan pinjaman utang (iqradh). Atau juga berarti القطع sebagaimana dikemukakan oleh Sayyid Sabiq dalam Fiqh As-Sunnah (1971. Vol. 3:182), Mustafa al-Bugha, Musthofa Al-Khin Ali Asy-Syurbaji. Dalam Fiqh alManhaji (1992. Vol. 6:101), karena harta yang diambil oleh orang yang meminjamkan memotong sebagian hartanya.

Sedangkan secara terminologi, para ahli fiqih (fuqaha') madzhab Syafi'i, mendeskripsikan Qardh sebagai berikut:

1. Abdul Rahman Al-Jaziri (2003. Vol. 2:303)

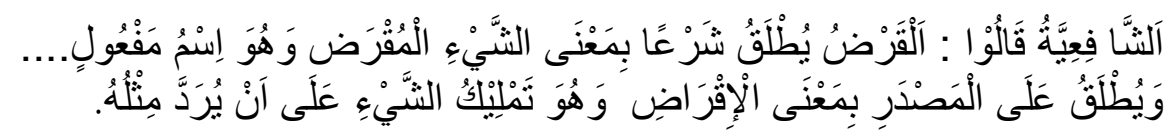

'Syafi' 'iyah berpendapat bahwa Qardh dalam istilah syara' digunakan dalam bentuk kata benda bermakna "sesuatu yang dipinjamkan", dan bentuk mashdar dengan makna "peminjaman". Artinya, Qardh adalah memberikan hak milik atas sesuatu kepada orang lain untuk dikembalikan dalam pepadannya."

2. Abu Abdul Mu'thi Muhammad bin Umar bin Ali Nawawi (2003:240),

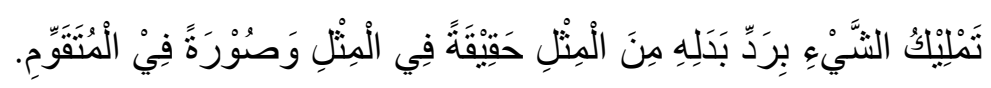

"Qardh adalah memberikan hak milik atas sesuatu dengan ketentuan mengembalikan pepadan (mitsli) dari harta mitsli dan mengembalikan qimah pada harta qimi (mutaqawwim)".

3. Sayyid Sabiq (1971. Vol. 3:182):

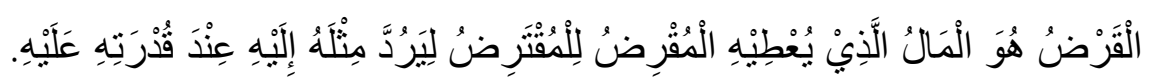

"Qardh adalah harta yang diberikan pihak muqridh kepada muqtaridh dengan ketentuan muqtaridh mengembalikan pepadan atau penggantinya setelah ia mampu”.

4. Mustafa al-Bugha, Mustafa Al-Khin, Ali Asy-Syurbaji (1992. Vol. 6:101)

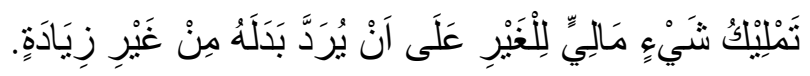

Jurnal Darussalam; Jurnal Pendidikan, Komunikasi dan Pemikiran Hukum Islam Vol. XI, No 2:408-423. April 2020. ISSN: 1978-4767 (Cetak), ISSN: 2549-4171(Online) Terakreditasi Nasional. SK. No.36/E/KPT/2019 
"Qardh adalah memberikan kepemilikan harta dengan ketentuan adanya keharusan mengembalikan penggantinya tanpa ada unsur tambahan."

5. Abu Bakar Syatha (2010. vol. 3:58)

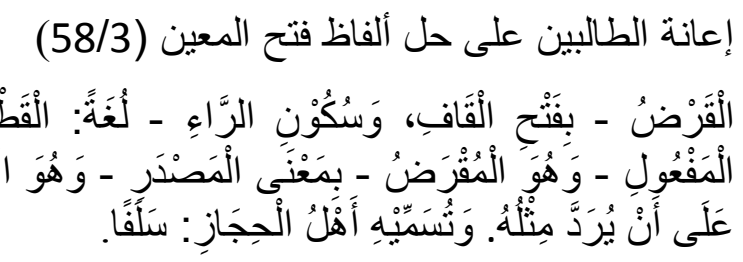

Qardh, dengan Qaf difathah dan ro' yang disukun menurut bahasa berarti potongan. Sedangkan menurut Qardh dalam istilah syara' digunakan dalam bentuk kata benda bermakna "sesuatu yang dipinjamkan", dan bentuk mashdar dengan makna "peminjaman". Artinya, Qardh adalah memberikan hak milik atas sesuatu kepada orang lain untuk dikembalikan dalam pepadannya.Ahli Hijaz juga menamakan akad Qardh ini dengan istilah salaf"

\section{Landasan Hukum Akad Qardh}

Diantaranya ada dalam QS. al-Muzammil ayat 20, QS al-Baqarah ayat 245, QS al-Hadid ayat 11. Sedangkan di dalm as-Sunnah ada dalam HR. al-Bukhari dan Muslim, HR. Ibnu Majah dari Ibnu Mas'ud (2430), HR. Ibnu Majah dari Anas Bin Malik (2431) serta dari ijma' yakni kesepakatan para ulama tentang suatu masalah agama. Berdasarkan pada ayat-ayat dan hadis-hadis dan kaidah fiqh, kaum muslimin sepakat bahwa Qardh (utang piutang) itu diperbolehkan.

\section{Hukum Akad Qardh}

Abu Abdul Mu’thi Muhammad bin Umar bin Ali Nawawi (2003: 240-241) menjelaskan hukum akad Qardh sebagai berikut:

1. Sunah

Hukum asal akad Qardh adalah sunah karena merupakan suatu akad kebajikan (tabarru') yang merupakan salah satu tujuan dan cita-cita syari'at (Maqashid as-Syari'ah). Akad Qardh hukumnya sunnah jika: a) Muqtaridh bukan orang yang terpaksa berutang. Jika ia terpaksa maka hukumnya wajib atas muqridh, b) Muqridh tidak mengetahui atau menyangka jika muqtaridh mentransaksikan uang pinjamannya pada perbuatan maksiat.

2. Haram

Hukum akad Qardh menjadi haram jika: a) Muqridh mengetahui atau menyangka bahwa muqtaridh mentransaksikan uang pinjamannya pada 
perbuatan maksiat atau perkara haram, b) Muqtaridh menyembunyikan kekayaannya dan menampakkan kesulitannya dan tidak disadari atau diketahui oleh muqridh saat Qardh berlangsung. Atau sebaliknya, yakni muqtaridh menampakkan seolah ia kaya dan menyembunyikan keadaannya yang sebenarnya bahwa ia sebenarnya tidak mampu pada saat Qardh berlangsung karena adanya kesamaran (tadlis). Muqtaridh bukan orang yang terpaksa dan tidak ada tujuan membayar utangnya karena mudahnya mendapatkan pinjaman seperti seseorang yang berutang kepada teman atau kerabatnya namun tidak berkeinginan untuk membayarnya. Qardh semacam ini tetap sah namun hukumnya haram.

3. Makruh

Akad Qardh menjadi makruh jika muqridh mengetahui atau menyangka jika muqtaridh akan mentransaksikan pinjamamnnya pada perkara yang makruh, atau muqridh mengetahui jika muqtaridh tidak berkeinginan membayar utangnya kelak tanpa ada hajat (yang mendesak).

4. Mubah

Akad Qardh bisa menjadi mubah jika dilakukan seperti seorang muqridh meminta orang (muqtaridh) yang tidak membutuhkan untuk berutang kepadanya karena dalam hal ini tidak ada unsur meringankan beban orang lain, hal ini dilakukan hanya karena tujuan menjaga hartanya dengan menyerahkannya menjadi tanggungan muqtaridh sebagaimana yang diterangkan dalam hadis.

Sementara Wahbah Az-Zuhaili (2004. vol. 4:720) menyatakan bahwa hukum Qardh disunahkan bagi pihak muqridh (kreditur) dan mubah bagi pihak muqtaridh (debitur).

\section{Syarat dan Rukun Akad Qardh}

1. Syarat sah Qardh

Syarat sah akad Qardh antara lain: a) Qardh atau barang yang dipinjamkan harus barang yang memiliki manfaat, tidak sah jika tidak ada kemungkinan pemanfaatan karena Qardh adalah akad terhadap harta, b) Akad Qardh tidak dapat terlaksana kecuali dengan ijab dan qobul seperti halnya dalam jual beli.

2. Rukun Qardh

Jurnal Darussalam; Jurnal Pendidikan, Komunikasi dan Pemikiran Hukum Islam Vol. XI, No 2:408-423. April 2020. ISSN: 1978-4767 (Cetak), ISSN: 2549-4171(Online) Terakreditasi Nasional. SK. No.36/E/KPT/2019 
Struktur atau rukun akad Qardh ada empat, yaitu muqridh, muqtaridh, muqradh, dan sighat: a) Muqridh adalah pihak yang memberikan pinjaman (kreditur). Sulaiman al-Jamal (2009. vol. 3:275) menyatakan bahwa ada dua syarat yang harus dipenuhi seorang muqridh, yaitu: 1) Mukhtar. Yakni seorang muqridh melakukan akad Qardh atas inisiatifnya sendiri, tidak dalam keadaan terpaksa. 2) Ahli tabarru', Yaitu orang yang memiiki kebebasan untuk mentrasaksikan harta secara non-komersial, atau juga bisa disebut dengan istilah mutlaq at-tasharruf sebagaimana dalam bai'. Oleh karenanya, seorang yang tidak memiliki kriteria ini seperti wali harta anak kecil, orang gila dan lain-lain, tidak sah mengadakan akad Qardh menggunakan harta orang yang menjadi tanggungan (mawli) nya kecuali dalam keadaan darurat saja. Pensyaratan harus ahli tabarru' karena akad Qardh merupakan akad yang semi tabarru' (syubhahTabarru') karena adanya konsekuensi keharusan mengembalikan pengganti harta yang dipinjamkan (muqradh) atas muqtaridh setelah berakhirnya masa Qardh. b) Muqtaridh adalah pihak yang menerima pinjaman utang (debitur). Syarat muqridh ada dua, yaitu: 1) mukhtar yakni atas kehendak sendiri atau tidak karena terpaksa. 2) Ahliyyah mu'amalah, yaitu orang yang baligh, berakal sehat dan tidak sedang dibekukan tasarufnya (hajr) meskipun tidak memiliki kebebasan tasaruf (ahli at-tabarru' atau muthlaq at-tasharruf). Karenanya, seorang wali dari harta anak kecil atau orang gila boleh atau sah menjadi seorang muqtaridh atas nama orang yang berada dibawah otoritasnya (mawli), bahkan seorang budak mukatab ataupun budak yang mendapatkan izin dari tuannya juga sah menjadi muqtaridh karena mereka termasuk ahliyyah mu'amalah (Sulaiman al-Jamal, 2009. vol. 3:275). c) Muqradh adalah obyek dalam akad Qardh (debit). Muqradh harussesuatu yang sah untuk diperjual-belikan, dan bisa dispesifikasi melalui kriteria (shifah) seperti muslamfih dalam akad salam. Karena akad Qardh termasuk akad mu'awadlah, yakni memberikan hak milik kepada orang lain dengan adanya pengganti ('iwadl) seperti dalam akad salam. Sesuatu yang tidak bisa di spesifikasi tidak bisa dijadikan muqradh karena tidak memiliki padanan (mitsli). Namun menurut satu versi, sesuatu yang tidak dapat 
dispesifikasi bisa dijadikan muqradh dengan menjadikan qimah sebagai padanannya (Asy-Syiraziy, 2010.vol. 2: 83).

"Qardh diperbolehkan pada semua harta yang bisa dispesifikasi melalui sifat, Karena akad Qardh termasuk akad mu'awadlah, yakni memberikan hak milik kepada orang lain dengan adanya pengganti ('iwadh) yang menjadi tanggungan. Oleh karenanya, boleh memberikan hak milik atas harta yang dapat di spesifikasi seperti dalam akad salam. Sesuatu yang tidak bisa di spesifikasi seperti perhiasan dan lainnya memiliki dua pendapat; pertama, tidak bisa dijadikan muqradh karena tidak memiliki padanan (mitsli), sedangkan akad qardh merupakan akad yang mengharuskan menegembalikan padanan sementara barang yang tidak dapat dispesifikasi melalui sifat tidak memiliki padanan. Kedua, boleh dengan menjadikan qimah sebagai padanan yang harus ditanggung oleh muqtaridh."

Meskipun antara akad Qardh dan salam mempunyai beberapa persamaan, bukan berarti segala sesuatu yang bisa diakadi salam juga bisa diakadi Qardh, begitu pula sebaliknya. Seperti: Meminjamkan budak perempuan (jariyah) kepada orang yang halal untuk meng-istimta'nya (menikmati anggota tubuhnya). Hal ini karena sama halnya dengan meminjmkan budak perempuan untuk melakukan sex bebas yang dilarang. (Jalaluddin al-Mahalli, 2010. vol. 2: 411-412).

Boleh meminjamkan sesuatu yang dapat diakadi salam seperti hewan dan lainnya kecuali jariyah yang halal dinikmati oleh muqtaridh menurut qaul adzhar yang menyatakan bahwa muqradh menjadi milik muqtaridh setelah qabdh. Hal ini dikarenakan adamnya kemungkinan muqtaridh dapat menggaulinya sebelum muqradh (jariyah) tersebut diminta oleh muqridh. Maka hal ini sama seperti meminjamkan budak jariah untuk melakukan seks.

Sah meminjamkan sepotong roti karena telah berlaku secara massif (Khatib As-Syarbini, vol. 2:148).

Tidak diperbolehkan meminjamkan sesuatu yang tidak bisa diakadi salam, seperti jariyah dan anaknya, perhiasan dan sesamanya menurut qaul ashah. Karena sangat sulit atau tidak mungkin mengembalikan pepadan (mitsli) dari sesuatu yang tidak dapat dispesifikasi atau sesuatu yang langka. Menurut pendapat kedua, diperbolehkan sebagaimana bai'. Perbedaan ini terjadi apakah yang wajib dikembalikan adalah mistli atau qimahnya seperti yang dijelaskan dalam kitab muharrar. Jika mengikuti qaul pertama yakni qaul adzhar, maka diperbolehkan, jika tidak maka tidak diperbolehkan. Ada pengecualian dari keterangan diatas, yakni meminjamkan sepotong roti dengan sistem timbangan karena terjadi secara massif diberbagai daerah meskipun al-Baghawi

Jurnal Darussalam; Jurnal Pendidikan, Komunikasi dan Pemikiran Hukum Islam Vol. XI, No 2:408-423. April 2020. ISSN: 1978-4767 (Cetak), ISSN: 2549-4171(Online) Terakreditasi Nasional. SK. No.36/E/KPT/2019 
melarangnya. Versi lain bahkan memperbolehkan dengan sistem hitungan atau jumlah.

d) Shighat dalam akad Qardh adalah ijab yang berupa penyerahan kepemilikan dari pihak muqridh kepada muqtaridh dengan kewajiban mngembalikan gantinya (badal), dan qabul yang berupa persetujuan dari pihak muqtaridh dari ijab yang disampaiakan pihak muqridh. Shighah dapat berupa ucapan yang jelas dan tidak memiliki ambiguitas makna (sharih), dapat pula berupa ucapan sindiran (kinayah). Syarat shighah dalam akad Qardh sama dengan syarat shigah pada akad mu'awadhah lainnya. Akan tetapi, menurut satu versi, qabul tidak disyaratkan dalam akad Qardh karena Qardh adalah suatu bentuk perizinan untuk menggunakan sesuatu dengan konsekuensi menggantinya (ibahah bi syarth adl-dlaman) (Al-Khatib AsySyarbini, 1997. vol. 2: 147).

\section{Konsekuensi Hukum dalam Akad Qardh}

Setelah akad Qardh telah terpenuhi syarat dan rukunnya, maka kepemlikan atas muqradh berpindah kepada muqtaridh dengan konsekuensi ia harus mengembalikan gantinya saat pihak muqridh memintanya kembali. Lalu apakah perpindahan hak milik ini terjadi karena adanya penerimaan ( $q a b d l)$ atau adanya pentransaksian (tasharruf)

Menurut Qaulashah, muqtaridh berstatus memiliki muqradh sejak penerimaan ( $q a b d l)$ karena muqtaridh boleh mentasarufkanmuqradh setelah terjadinya penerimaan ( $q a b d l$ ) menurut kesepakatan ulama'. Hal ini menunjukkan bahwa harus adanya hak kepemilikan atas sesuatu sebelum ditransaksikan. Menurut versi ini, muqridh tidal boleh menarik barang yang dipinjamkannya (muqradh) kecuali atas kerelaan pihak muqtaridh akan tetapi ia boleh meminta pengganti (badal) dari muqradh. Karena yang wajib dalam akad Qardh adalah pengganti (badal). Namun versi lain memperbolehkan penarikan barang yang dipinjamkan ('ainulmuqradh) selagi muqrodh masih utuh dan tidah terikat dengan hak tertentu seperti muqradh yang digadaikan.

Menurut muqabil ashah, muqtaridh berstatus memiliki muqradh terhitung sejak ia mentasarufkan muqradh dengan akad yang bisa menghilangkan hak kepemilikan terhadap sesuatu seperti akad jual beli, hibah, wakaf dan akad tasaruf

Jurnal Darussalam; Jurnal Pendidikan, Komunikasi dan Pemikiran Hukum Islam Vol. XI, No 2:408-423. April 2020. ISSN: 1978-4767 (Cetak), ISSN: 2549-4171(Online) Terakreditasi Nasional. SK. No.36/E/KPT/2019 
yang menghilangkan hak milik lainnya. Karena adanya transaksi ini menunjukkan adanya hak milik muqtaridh atas muqradh. Menurut versi ini, sebelum muqtaridh mentasarufkan muqradh yang bisa menghilangkan hak milik, kedua belah pihak boleh membatalkan akad Qardh dengan menarik kembali muqradh oleh muqridh dan mengembalikannya oleh muqtaridh.

Letak perbedaan ini terjadi pada muqradh yang berupa sesuatu yang membutuhkan nafkah (biaya perawatan) atau barang yang menghasilkan produktivitas (manfa'ah) (Mustafa al-Bugha, Musthofa Al-Khin, Ali AsySyurbaji, 1992. Vol. 6:107-108).

\section{Persyaratan dalam Akad Qardh}

Secara umum, syarat atau klausal dalam akad qardh ada tiga, yaitu syarat fasid yang $\mathrm{mufsid}$, syarat fasid yang tidak $\mathrm{mufsid}$, dan syarat shahih.

1. Syarat fasid yang mufsid

Yaitu suatu klausal yang memberikan keuntungan (manfa'ah) bagi pihak muqridh saja. Seperti memberikan pinjaman utang dengan syarat mengembalikan dengan nilai lebih. Klausal seperti ini dapat membatalkan (mufsid) dalam akad Qardh karena ternasuk riba Qardhi.

Selain itu, klausal seperti ini menyalahi konsekuensi akad Qardh (munafin li muqtadla al-'aqd) karena spirit akad Qardh dibangun atas dasar prinsip tolong-menolong (irfaq), sehingga akan sangat kontradiktif jika akad Qardh digunakan untuk mencari keuntungan.

Hukum akad Qardh yang menguntungkan pihak muqridh ini, akan batal jika klausal disyaratkan dalam akad ( $f i$ shulbi al-'aqd) apabila tidak disyaratkan sama sekali, maka sah bahkan termasuk sunah. Apabila klausal disyaratkan diluar akad (kharij al- 'aqd) maka menurut syafi'iyah hukumnya sah namun makruh sedangkan menurut aimmahTsalatsah hukumnya haram (Zainuddin al-Malibari \& Abu Bakar Syatha, 2010. Vol. 3:65).

2. Syarat fasid yang tidak $m u f$ sid

Yaitu klausal yang memberikan keuntungan bagi pihak muqtaridh saja, atau klausal yang memberikan keuntungan bagi kedua belah pihak namun keuntungan yang diperoleh muqtaridh lebih besar. Contoh pertama: seseorang memberikan pinjaman sebesar Rp. 1.000.000,00 dengan syarat 
boleh mengembalikan sebesar 900.000,00. Sementara yang kedua; seorang muqridh memberikan pinjaman dengan syarat dibayar setelah satu tahun kemudian, karena pihak muqridh mempunyai tujuan yang baik dalam pensyaratan ini, misalnya agar tidak dicuri atau karena muqtaridh belum mampu membayar utangnya (Sulaiman al-Bujairomi,2003. vol. 2: 465-466).

Dalam madzhab syafi'iyah, klausal yang berupa penyaratan tempo dalam akad Qardh juga termasuk syarat fasid yang tidak $m u f$ sid karena adanya nilai tambah yang menguntung salah satu pihak. Sementara akad Qardh tidak mengizinkan adanya kelebihan (tafadlul). Namun syarat ini tidak mufsid karena tidak menguntungkan pihak muqridh sebagaimana contoh diatas. (Asy-Syarwani, 2013. Vol. 6:264).

Lebih dari itu, substansi akad Qardh adalah pemberian izin mentransaksi muqradh dengan sistem kewajiban mengembalikan ganti, sehingga akad Qardh menjadi alasan bagi muqridh dapat menagih muqradh secara langsung (halan) dan hak ini tidak hilang karena adanya persyaratan tempo (ajal) sebab penempoan ini hanya sekedar bentuk kemurahan yang dijanjikan oleh muqridh.

Kendati secara yuridis hak tagih muqridh dalam akad Qardh adalah secara langsung setelah akad, namun secara etis, muqridh tidak diperkenankan menagih utang selama muqtaridh belum mampu membayar. Sebagaimana firman Allah dalam QS. Al-Baqarah ayat 280.

3. Syarat Shahih

Yaitu klausul yang disyaratkan dalam akad hanya sebagai jaminan (watsiqah), bukan untuk mencari keuntungan (manfa'ah). Seperti syarat gadai (rahn), persaksian (isyhad), syarat adanya penanggung (kafil) (Zakaria alAnshari. Vol. 4: 353).

\section{Metode Penelitian}

Metode yang digunakan dalam penelitian ini adalah metode kualitatif dengan jenis naturalistik yakni jenis penelitian dengan mengutamakan penekanan pada proses dan makna yang tidak diuji, atau diukur dengan setepat-tepatnya dengan data yang berupa data deskriptif. Penekanan analisis isi sebagai suatu teknik 
penelitian untuk membuat inferensi-inferensi yang dapat ditiru (replicable) dan data sahih dengan memperhatikan konteksnya.

Adapun yang dimaksud penelitian deskriptif dalam penelitian ini yaitu mendeskripsikan fatwa DSN-MUI tentang akad Qardh melalui pemikiran madzhab Syafi'i, memahami dan kemudian menganalisis kesesuaian fatwa tersebut dengan pemikiran Syafi'i secara sistematis dan subyektif (Boedi Abdullah dan Saebani, 2014:17).

\section{Hasil}

Majelis Ulama' Indonesia (MUI) yang merupakan wadah musyawarah para ulama', zu'ama, dan cendekiawan muslim serta menjadi pengayom bagi seluruh muslim Indonesia adalah lembaga paling berkompeten bagi pemecahan dan menjawab setiap masalah sosial keagamaan yang senantiasatimbul dan dihadapi masyarakat serta telah mendapat kepercayaan penuh, baik dari masyarakat maupun pemerintah (Dewan Syariah Nasional MUI 2014: 18). Berdasarkan pada SK Dewan Pimpinan MUI tentang Pembentukan Dewan Syariah Nasional (DSN) No. Kep-754/MUI/II/1999, yaitu bahwa salah satu yang menjadi tugas dan wewenang DSN ialah mengeluarkan fatwa (Dewan Syariah Nasional MUI, 2014:7).

Fatwa yang menjelaskan tentang al-Qardh sendiri telah tertuang pada fatwa DSN MUI No. 19/DSN-MUI/IV/2001 tentang al-Qardh yang menetapkan ketentuan umum berikut:

1. Al-Qardh adalah pinjaman yang diberikan kepada nasabah (muqtaridh) yang memerlukan.

2. Nasabah al-Qardh wajib mengembalikan jumlah pokok yang diterima pada waktu yang telah disepakati bersama.

3. Biaya administrasi dibebankan kepada nasabah.

4. LKS dapat meminta jaminan kepada nasabah bilamana dipandang perlu.

5. Nasabah al-Qardh dapat memberikan tambahan (sumbangan) dengan sukarela kepada LKS selama tidak diperjanjikan dalam akad. Jika nasabah tidak dapat mengembalikan sebagian atau seluruh kewajibannya pada saat yang telah disepakati dan LKS telah memastikan ketidakmampuannya, LKS

Jurnal Darussalam; Jurnal Pendidikan, Komunikasi dan Pemikiran Hukum Islam Vol. XI, No 2:408-423. April 2020. ISSN: 1978-4767 (Cetak), ISSN: 2549-4171(Online) Terakreditasi Nasional. SK. No.36/E/KPT/2019 
dapat: a) memperpanjang jangka waktu pengembalian, atau b) menghapus (write off) sebagian atau seluruh kewajibannya.

\section{E. Pembahasan}

Fatwa MUI yang menjelaskan tentang al-Qardh diaplikasikan dalam perbankan melalui adanya aqad Qardhyang biasanya diterapkan sebagai berikut:

1. Sebagai produk pelengkap kepada nasabah yang telah terbukti loyalitas dan bonafiditas-nya yang membutukkan dana talangan segera untuk masa yang relatif pendek. Nasabah tersebut akan mengembalikan secepatnya sejumlah uang yang dipinjamnya itu.

2. Sebagai fasilitas nasabah yang memerlukan dana cepat sedangkan ia tidak bisa menarik dananya karena misalnya, tersimpan dalam bentuk deposito.

3. Sebagai produk untuk menyumbang usaha yang sangat kecil, atau membantu sektor sosial. Guna pemenuhan skema khusus ini telah dikenal suatu produk khusus yaitu Qardh al-hasan (Muhammad Syafi'i Antonio, 2001: 133).

Sifat Qardh tidak memberi keuntungan finansial. Karena itu, pendanaan Qardh dapat diambil menurut kategori berikut :

1. Qardh yang diperlukan untuk membantu keuangan nasabah secara cepat dan berjangka pendek, seperti talangan danda di atas, dapat diambilkan dari modal bank.

2. Qardh yang diperlukan untuk membantu usaha sangat kecil dan keperluan sosial, dapat bersumber dari dana zakat, infaq, dan shadaqah, dan juga dari pendapatan bank yang dikategorikan seperti jasa nostro di bank koresponden yang konvensional, bunga atas jaminan L/C di bank asing, dan sebagainya.

Salah satu pertimbangan pemanfaatan dana-dana ini adalah kaidah akhaffu dhararain (mengambil mudharat yang lebih ringan). Hal ini mengingat jika dana umat Islam dibiarkan di lembaga-lembaga nonmuslim mungkin dapat dipergunakan untuk sesuatu yang merugikan Islam, misalnya dana kaum muslimin arab di bank-bank Yahudi Switzerland. Oleh karenanya, dana yang parkir tersebut lebih baik diambil dan dimanfaatkan untuk penanggulangan 
bencana alam atau membantu dhu'afa (Antonio, 2001:133). Ketentuan umum akad Qardh yang ditetapkan DSN-MUI adalah:

1. Al-Qardh adalah pinjaman yang diberikan kepada nasabah (muqtaridh) yang memerlukan.

2. Nasabah al-Qardh wajib mengembalikan jumlah pokok yang diterima pada waktu yang telah disepakati bersama.

3. Biaya administrasi dibebankan kepada nasabah.

4. LKS dapat meminta jaminan kepada nasabah bilamana dipandang perlu.

5. Nasabah al-Qardh dapat memberikan tambahan (sumbangan) dengan sukarela kepada LKS selama tidak diperjanjikan dalam akad.

6. Jika nasabah tidak dapat mengembalikan sebagian atau seluruh kewajibannya pada saat yang telah disepakati dan LKS telah memastikan ketidak mampuannya, LKS dapat: a) Memperpanjang jangka waktu pengembalian, atau b) Menghapus (write off) sebagian atau seluruh kewajibannya.

Dari ayat ketentuan umum tersebut, peneliti menyimpulkan bahwa:

1. Butir pertama dan kedua telah sesuai dengan definisi akad Qardh yang telah ditetapkan oleh ulama' madzhab Syafi'i.

2. Dalam butir ketiga yang membebankan biaya administrasi kepada pihak muqtaridh (nasabah), peneliti belum menemukan adanya pendapat ulama' madzhab Syafi'i yang memperbolehkannya dan justru hal ini mengindikasikan adanya praktik riba qardh. Akan tetapi, menurut standar yang dikeluarkan oleh the Accounting and Auditing Organisation for Islamic Finance Institutions (AAOFI), pembebanan biaya ini tidak dilarang, namun dengan ketentuan yang sangat ketat bahwa biaya tersebut harus merupakan actual cost. Biaya-biaya tidak langsung seperti biaya pegawai, biaya sewa dan pengeluaran kantor lainnya, atau kewajiban-kewajiban lain tidak dapat diperhitungkan dalam actual cost tersebut (Khir, Gupta, \& Shanmugam, 2008:187 dalam Sutan Remy Sjahdeini, 2014:343).

3. Butir keempat yang memperbolehkan pihak LKS (muqridh) boleh meminta jaminanpun telah sesuai dengan ketentuan yang ditetapkan oleh 
ulama'madzhab Syafi'i. Seperti yang diterangkan oleh Imam Zakaria alAnshori dalam kitab Asna al-Mathalib (4:353).

$$
\begin{aligned}
& \text { أسنى المطالب في شرح روض الطالب (2/ 143) }
\end{aligned}
$$

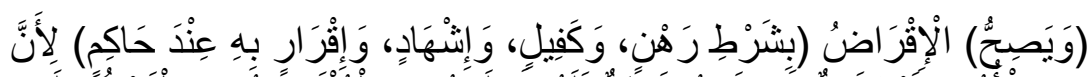

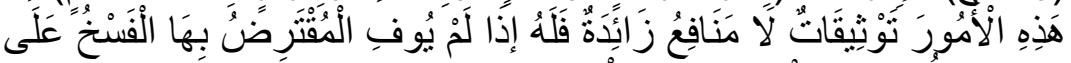

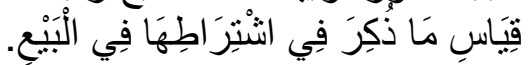

Qardh sah dengan persyaratan rahn, kafil (penjamin), isyhad (persaksian), dan ikrar dihadapan hakim. Karena semua itu hanya merupakan penguat bukan tambahan manfaat. Oleh karenanya, muqridh berhak membatalkan akad qardh ketika pihak muqtaridh tidak mau melakukannya.

4. Butir kelima, memperbolehkan nasabah memberikan tambahan secara sukarela kepada pihak LKS asal tidak diperjanjikan dalam akad, dengan bertendensi pada hadits riwayat Al-Bukhari yang artinya: "sebaik-baik kalian adalah yang paling baik dalam membayar hutang".

Madzhab Syafi'i memperbolehkan, bahkan praktik semacam ini disunahkan. Namun, jika tambahan tersebut disyaratkan diluar akad (kharij al-'aqd), madzhab Syafi'i menghukumi makruh, sementara a'immah tsalatsah menghukumi haram. (Zainuddin Al-Malibari \& Abu Bakar Syatha, 2010. vol. 3: 65).

5. Butir keenam, Jika nasabah tidak dapat mengembalikan sebagian atau seluruh kewajibannya pada saat yang telah disepakati dan LKS telah memastikan ketidak mampuannya, LKS dapat: a) memperpanjang jangka waktu pengembalian, atau b) menghapus (write off) sebagian atau seluruh kewajibannya. Butir ini telah sesuai pula dengan hukum Islam dan Madzhab Syafi'i. Sebagaimana yang dijelaskan dalam surat Al-Baqarah ayat 280. formulasi hak tagih muqridh ini juga tidak kontradiktif dengan surat AlBaqarah ayat 282 yang menginstruksikan pencatatan tempo pembayaran utang (Fakhr ar-Razi. vol 7:89).

$$
\text { تفسير الرازي مفاتيح الغيب أو التفسير الكبير (17/ 90) }
$$

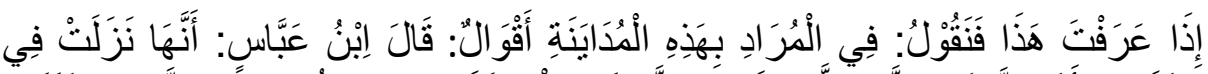

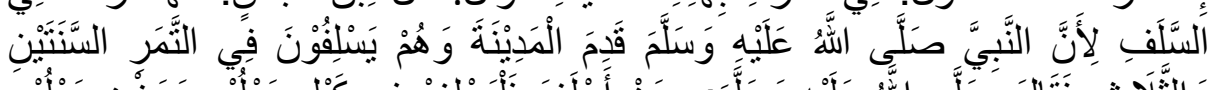

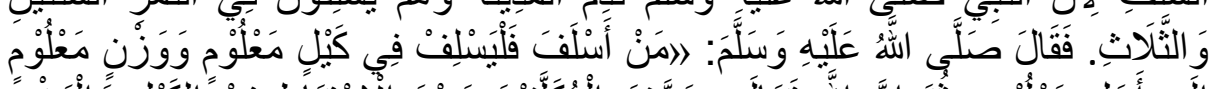

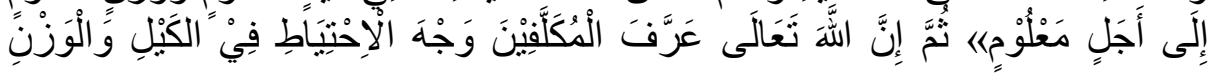




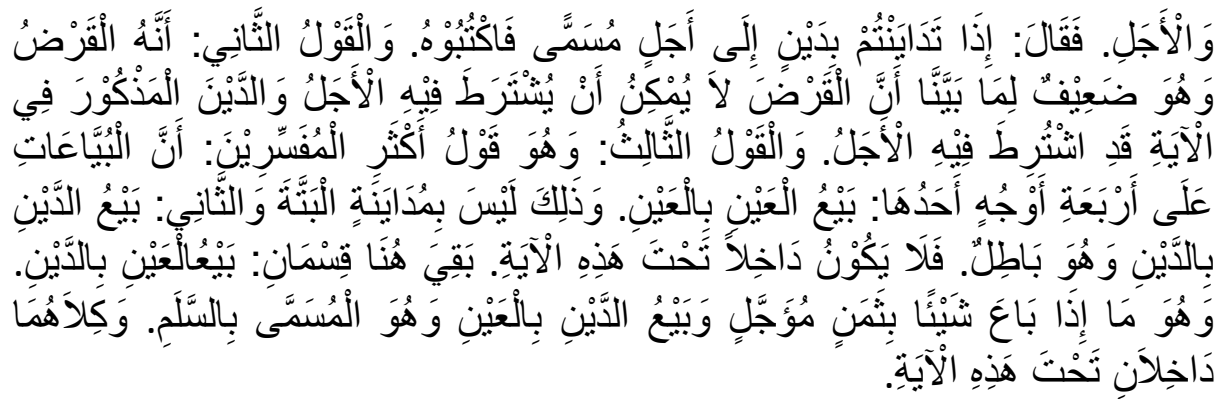

Dengan demikian, dapat ditarik suatu kesimpulan bahwa Fatwa DSN-MUI tentang akad Qardh telah sesuai dengan konsep qardh yang telah ditetapkan oleh madzhab Syafi'i, baik dalam ketentuan hukum maupun konsekuensinya, hanya saja ada beberapa poin dari fatwa tersebut yang belum dapat peneliti simpulkan melalui kitab-kitab mu'tabarah madzhab Syafi'i.

\section{F. Kesimpulan}

Berdasarkan pembahasan mengenai fatwa DSN-MUI dan para ulama' syafi'iyah yang peneliti uraikan diatas, peneliti mengambil kesimpulan bahwa akad qardh merupakan suatu pinjaman yang diberikan oleh pihak muqridh kepada muqtaridh yang membutuhkan dengan ketentuan kewajiban mengembalikan atau melunasinya pada waktu yang telah ditentukan tanpa ada unsur tambahan. Akad qardhsalah satu akad dalam mu'amalah yang disyariatkan oleh Islam. Dasar hukum akad Qardh adalah Al-Qur'an, Sunah, ijma' dan Qiyas.

Fatwa DSN MUI No. 19/DSN-MUI/IV/2001 tentang al-qardhtelah sesuai dengan perspektif madzhab Imam Syafi'i baik dari segi konsep maupun konsekuensinya. Fatwa yang menjelaskan tentang al-Qardh tersebut telah tertuang pada fatwa DSN MUI No. 19/DSN-MUI/IV/2001 tentang al-Qardh yang meliputi ketentuan umum, sanksi, sumber dana, maupun ketentuan lainnya. Fatwa tersebut dan menganalisanya dengan pemiikiran madzhab Syafi' 'i.

\section{Daftar Pustaka}

Abdullah. Boedi \& Saebani. B.A. 2014. Metode Penelitian Ekonomi Islam Mu'amalah. Bandung: CV Pustaka Setia.

Al-Bantani. Abu Abdul Mu'thi Muhammad bin Umar bin Ali Nawawi. 2003. Nihayah az-Zain. Surabaya: al-Hidayah. 
Al-Bujairomi. Sulaiman bin Muhammad. 2003. Hasyiyah al-Bujairomi 'ala alManhaj. Beirut. Lebanon: Daar al-Kotob al-Ilmiyah.

Al-Haitami. Ibnu Hajar \& Abdul Hamid bin al-husain Asy-Syarwani. 2005. Tuhfah al-Muhtaj wa Hawasyi Asy-Syarwani Wa al-Ubadi. Beirut. Lebanon: Dasar al-Kotob al-Ilmiah.

Al-Jamal. Syaikh Sulaiman bin Manshur al-Ijaili. 2009. Hasyiyah al-Jamal Beirut Lebanon: Dar al-fikr.

Al-Mahalli. Jallaludin Muhammad. 2010. Kanzu al-Rogibin Syarah Minhaj alThalibin. Lebanon: Daar al-Kutub Ilmiah.

Al-Maribari. Zainuddin \& Abu Bakar Syatha. 2010. Fath Al-Mu'in Wa I'anah AlThalibin. Beirut. Lebanon: Dar al-Kotob Ilmiyah.

Asy-Syarbini. Syamsuddin. Muhammad bin Ahmad Al-Khotib. 1997. Mughi alMuhtaj ila ma'rifati Ma'ani Alfadh al-Minhaj. Beirut Lebanon: Dar alKotob al-Ilmiyah.

Asy-Syarwani. Abdul Hamid bin al-Husain. 2013. Hawasyi al-Syarwani 'ala Tuhfah al-Muhtaj. Beirut. Lebanon: Daar al-Kotob Ilmiah.

Antonio. Muhammad Syafi'i. 2001. Bank Syariah dari Teori ke Praktik. Jakarta: Gema Insani.

Ar-Razi. Fakhruddin Muhammad bin Umar bin Husain. Mafatihul Ghoib /Tafsir Al-Kabir. Maktabah Syamilah.

Dewan Syariah Nasional MUI. 2014. Himpunan Fatwa Keuangan Syariah Jakarta: Erlangga.

Machmud. Amir \& Rukmana. 2002. Bank Syariah. Teori. Kebijakan dan Studi Empiris di Indonesia. Jakarta: Erlangga.

Mustofa Al-Khin.Dr Mustofa al-Bugha. Ali Asy-Syurbaji. 1992. Al-Fiqh AlManhaji Ala Al-Madzhab Asy-Syafi'i. Damaskus Syiria: Dar al-Qolam.

Sabiq. Sayyid. 1971. Fiqih As-Sunnah. Kairo. Mesir: Al-Fath Lil I'lam Al-'Arobi.

Jurnal Darussalam; Jurnal Pendidikan, Komunikasi dan Pemikiran Hukum Islam Vol. XI, No 2:408-423. April 2020. ISSN: 1978-4767 (Cetak), ISSN: 2549-4171(Online) Terakreditasi Nasional. SK. No.36/E/KPT/2019 